\section{Archæology, Anthropology and Breuil}

THE journal Man for December 1961 contains several interesting articles and an obituary of the late Abbé Breuil by Dr. Garrod. The obituary gives a good picture of a great man. His was a considerable influence on the thought of his time. The study of prehistoric man and the rise and fall of cultures in the past, not to mention the antiquity of 'ceremonial burial' and the occurrence of cave and home art, does affect to some extent man's general religious philosophic outlook on life. As Breuil vastly increased our knowledge of these subjects his life-history is a matter of interest. There have been several obituaries (see Nature, 191, 1246;1961), and Dr. Garrod in this one has done her job well. There is a small mistake about the start of prehistoric studies in Cambridge. The study of the subject was included in the Anthropological Tripos then just starting, and the diploma followed the establishment of the tripos, not preceding it. Classical archæology, of course, was an older development in the University. But this is only a trifle of interest locally. Dr. Garrod knew the "old boy' very well and her account of his life and work is well worth perusing.

\section{Wood Charcoal in Great Britain}

LITTLE is heard of the manufacture of wood charcoal in Great Britain, but the subject is comprehensively dealt with in the Forestry Commission's Forestry Record No. 19 (The Manufacture of Wood Charcoal in Great Britain. By L. Reynolds. Pp. 10. London: H.M.S.O., 1962. 3s. net). The demand is for leaf-tree (hardwood) charcoal, and conifers are not usually acceptable. Charcoal is used in a variety of ways, as a filler in rubber goods, paints and plastics, as a pigment in black paints, as an insulator, for absorbing gases and odours and also colours from liquids, and in case-hardening compounds for ferrous and nonforrous metals. It is used in many chemical processes and for pharmaceutical purposes. Only on a small scale is charcoal now used as a fuel in Britain. The leaflet describes the ways of manufacturing charcoal, the by-products obtained and a synopsis of the charcoal industry in Britain. In $1960,19,843$ tons of charcoal, valued at $£ 583,096$, were imported into Britain from fifteen countries. Imports amount, on the average, to about twice the home production, but 933 tons valued at $£ 60,530$ were exported.

\section{Butt-Rot and Death of Conifers}

ONE of the biggest problems confronting the forester in Britain is the damage done to woodlands by the fungus Fomes annosus; this problem is the subject of a recent Forestry Commission Leaflet (Leaflet No. 5: Fomes annosus: a Fungus causing Butt-Rot and Death of Conifers. Pp. 11. London: H.M.S.O., 1961. 1s. net). It appears that it can attack all species of conifer, that it is responsible for butt-rot and loss of increment, and that it can cause death to the treo. Wind-borne spores infect exposed woody tissues of conifors, mainly stumps, and the developing mycelium grows down into the root system of the stump. Root contacts are tho moans of carrying the infection into standing trees. Depending on site and species, the fungus may cause root-rot and death of the root system, or butt-rot. Under favourable conditions for the fungus, it may kill the tree. Broad-leaved trees on unsuitable sites for them may also be killed, but the real problem is concerned with the conifers, of which only the silver firs show any marked resistance to attack. Observations seem to point to there being certain inhibitory organisms in the soil which prevent or restrict root-surface growth of the fungus. These conditions exist on wot: acid, peat sites, where pine is grown pure on nonalkaline sites, and on old broad-leaved tree sites as long as stumps of the former trees remain. Roally satis. factory control measures on other sites have not yet been found, but, for the present, the Forestry Commission has adopted a routine creosoting of stumps. Research is being conducted into other means of stump protection against Fomes. This fungus is causing a serious economic loss in Britain's forests and it could quite easily become much more serious.

\section{Chemotherapy and Present-day Therapeutics}

A QUARTER of a century has elapsed since the introduction of the sulphonamides led to one of the greatest revolutions in the history of medicine. Ebrlich's dream of a therapia sterilisans magna has become a fact, though not in the sense that he conceived it. Rather is the practitioner faced with such a multiplicity of antibacterial agents that he often finds it difficult to decide which one should be used in any particular case. At one time it seemed as if the sulphonamides had had their day and were to be replaced by antibiotics. To-day it is clear that these two forms of 'chemotherapy' are complementaryand not mutually exclusive. To help to disentangle this chemotherapeutic skein, The Practitioner has issued a special number on chemotherapy (188. No. 1123; January 1962). The sixteen articles, together with one on present-day therapeutics, provide a comprehensive review of the subject in which the emphasis is placed on practical aspects. While the sulphonamides and the antibiotics provide the answer to most infectious diseases in temperate climates, there remains the vast residuum of tropical diseases, which explains why seven of the contributors deal with the chemotherapy of diseases endemic in vast areas of Africa and Asia, as well as Oceania. To help in unravelling the tangle of the multiplicity of proprietary names for the same drug, a selection of some of the newer and less familiar drugs mentioned by their official or approved names, along with their proprietary names, is included.

\section{Index Medicus}

Much has been written about the increasing difficulty of the research worker in finding out what work has been published in his field. With an increasing number of journals, publishing a logarithmically increasing number of articles, some research workers seem to have given up the task in despair. At present, the only hope at all seems to be a firstclass journal of abstracts or of titles. Both have disadvantages. The abstract may not necessarily describe the most important and relevant findings, while the title may give a quite wrong indication of what the article is about. Nevertheless, we should be content to a very large degree if we had a reliable, reasonably up-to-date and fairly comprehensive list of papers. Those who work in medicine and the medical sciences are fortunate. After a rather chequered history of more than 80 years, thero is now a new Index Medicus, published by the American Medical Association since January 1960, in 12 monthly parts. These are re-issued, again alphabetically, as the Cumulated Index Medicus at the end of each year, in two sections, subject and author. In its first year, there were 125,000 entries. It is estimated that, throughout the world, there were perhaps twice as: 